\title{
PO CO I JAK (NIE) UCZYĆ CUDZOZIEMCÓW FONETYKI JEZYKA POLSKIEGO?
}

Słowa kluczowe: nauczanie języka polskiego jako obcego, fonetyka, fonem, głoska

Streszczenie. Fonetyka nie jest eksponowaną płaszczyzną w nauczaniu języka polskiego jako obcego o nastawieniu komunikacyjnym, jednak skuteczność komunikacyjna zależy też od umiejętności odwzorowania przez studenta prawidłowej postaci brzmieniowej wyrazu, zwłaszcza w zakresie relewantnych fonologicznie cech głosek. Trudności studenta z prawidłową wymową wynikają z ukształtowania jego słuchu fonemowego i zautomatyzowania ruchów artykulacyjnych zgodnie z wymogami jego języka rodzimego, dlatego ogólna ekspozycja na brzmienie języka polskiego może być niewystarczająca. Uzasadnione jest skoncentrowanie się na różnicowaniu słuchem głosek polskich i prawidłowej ich wymowie już na początku nauki. Umożliwia to późniejsze odwoływanie się do wprowadzonych wzorców fonetycznych i zapobieganie powstaniu błędnych nawyków wymawianiowych. W pracy nad fonetyką należy skupić się zwłaszcza na najbardziej charakterystycznych opozycjach fonologicznych w języku polskim, z uwzględnieniem tych, które są istotne z punktu widzenia fleksji. Zasadne jest wprowadzanie fonemów w powiązaniu $\mathrm{z}$ alfabetem, ponieważ $\mathrm{w}$ nauce języka obcego student zapoznaje się z kodem fonetycznym i graficznym równolegle. Pozwala to na późniejsze wykorzystanie postaci ortograficznej do przypomnienia wymowy, poprawne zapisywanie wyrazów ze słuchu, a jednocześnie uniknięcie odczytywania nowych polskich wyrazów zgodnie z konwencją ortograficzną obcego języka. Ponadto umożliwia w przyszłości operowanie w mowie nazwami własnymi poznawanymi w postaci graficznej.

We współczesnym modelu nauczania języków obcych dominuje podejście komunikacyjne, którego teoretyczną podstawą jest przekonanie, że język należy postrzegać przede wszystkim w jego funkcji społecznej, jako narzędzie porozumiewania się. W rezultacie w dydaktyce wyraźnie przedkłada się kompetencję komunikacyjną, za której sprawdzian uznaje się efektywność przekazywania i pozyskiwania informacji odpowiednio do wymogów sytuacji, nad kompetencję lingwistyczną rozumianą jako znajomość kodu językowego i reguł systemowych.

*fpoeba@ug.edu.pl, Uniwersytet Gdański, Wydział Filologiczny, Instytut Filologii Polskiej, Katedra Języka Polskiego / Centrum Kultury i Języka Polskiego dla Cudzoziemców, ul. Wita Stwosza 55, 80-308 Gdańsk. 
Nauczanie języka kładące nacisk na to drugie uznaje się za nieco anachroniczne, będące zagrożeniem dla naturalności komunikacyjnej czy wręcz hamujące jej swobodę, a jednocześnie nieatrakcyjne dla studentów. Poprawność językowa nie jest przy takim podejściu celem głównym w nauczaniu, ustępuje płynności i skuteczności komunikacyjnej. Skrajnie postrzega się nawet kompetencje: komunikacyjną i lingwistyczną jako opozycyjne, co znajduje wyraz w takich na przykład hasłach, którymi reklamują się nauczyciele języków i szkoły językowe: Koniec nudnej gramatyki, zacznij wreszcie mówić!!!; Monotonne powtarzanie reguł gramatycznych? O nie! U nas porozmawiamy o tym, co Cię naprawdę interesuje - o muzyce, prasie mlodzieżowej, aktualnych wydarzeniach.

Jednakże czasy ostrego rozdzielania tych dwóch rodzajów kompetencji i postrzegania ich jako wyboru alternatywnego zaczynają już przemijać. W ostatnich latach nasila się krytyka postawy ignorowania błędów ucznia i zaniedbania kwestii uczenia gramatyki. Poprawność językowa jako zadanie w nauczaniu języków obcych powraca w nowej orientacji, ku której dziś zwraca się glottodydaktyka, przyznającej słuszność podejściom szerokim, nierygorystycznym, uznającej większy pluralizm metod i ich eklektyzm, a w ślad za tym dowartościowującej na powrót kształcenie językowe (Izdebska-Długosz 2016).

Nie jest tu moim celem wkraczanie w szerszą teoretyczną dyskusję nad miejscem i rolą gramatyki, a ściślej fonetyki, w dydaktyce języka obcego, niezależnie bowiem od przyjętego w tej sprawie stanowiska nie da się podważyć tezy, że nawet w podejściu mocno optującym za koncentracją na kompetencji komunikacyjnej kosztem lingwistycznej nie można fonetyki zignorować, ponieważ efektywność komunikacyjna w mowie zależna jest od realizacji fonetycznej wypowiedzenia. Zniekształcenie wyrazów, jeśli jest znaczne, może powodować, że przepływ informacji będzie zakłócony, a nawet nieskuteczny. Jak tę oczywistą obserwację przełożyć jednak na praktykę dydaktyczną? W jakim stopniu i na jakich konkretnie aspektach koncentrować się powinien nauczyciel? Na jakim etapie nauki?

Zacznijmy od podpowiedzi zawartych w kluczowych dokumentach określających standardy nauczania języka polskiego jako obcego, takich jak Opis standardów wymagań odnoszacych się do poszczególnych poziomów biegłości językowej w zakresie znajomości języka polskiego jako obcego zawartych w Rozporządzeniu Ministra Nauki i Szkolnictwa Wyższego z dnia 26 lutego 2016 r. w sprawie egzaminów z języka polskiego jako obcego. Nie znajdziemy ich tam wiele. Podczas gdy rejestry zagadnień gramatycznych w zakresie fleksji i składni są długie i niezwykle szczegółowe, zagadnień fonetycznych w zasadzie się nie wskazuje. Zastępują je bardzo ogólne uwagi na temat poprawności fonologicznej ${ }^{1}$, które odnaleźć można $\mathrm{w}$ opisach wymagań związanych z mówieniem. W dokumencie mówi się zatem o opanowaniu ,zasad wymowy i intonacji pozwalających na właściwe zrozumienie wyrażanych intencji oraz treści wypowiedzi” (poziom A2 i B1, dla po-

${ }^{1}$ Opracowane są one na bazie wytycznych Europejskiego systemu opisu ksztatcenia językowego: uczenie sie, nauczanie, ocenianie, por. ESOJK (Coste i in. 2003, p. 105). 
ziomu A1 dotyczy to „wyuczonych słów i wyrażeń”, których czytelność możliwa jest ewentualnie przy „pewnym wysiłku” odbiorcy), przy czym dozwala się odczuwalny wpływ wymowy języka rodzimego pod warunkiem niezakłócenia zrozumienia wypowiedzi, tym słabszy, im wyższy jest poziom biegłości językowej. Na poziomie C1 i C2 ,wymowa i intonacja zdających może zdradzać ich język rodzimy jedynie jako informacja o ich pochodzeniu, nie może jednak osłabiać płynności i swobody komunikacji." Zakłada się więc, że wymowa powinna się w miarę nauki doskonalić.

Warto zauważyć, że we wcześniejszym dokumencie z tego zakresu, a mianowicie w Rozporządzeniu Ministra Edukacji Narodowej i Sportu z dnia 15 października 2003 r. w sprawie egzaminów z języka polskiego jako obcego, już uchylonym, uwagi na ten temat były bardziej szczegółowe. I tak na poziomie podstawowym prócz ogólnej informacji, że błędy wymowy nie powinny uniemożliwiać zrozumienia sensu i intencji wypowiedzi, zamieszczono co do artykulacji głosek uwagę, że zdający ,,powinni właściwie wymawiać głoskę $y$ w opozycji do $i$ oraz $e$, głoski $a$ i $e$, głoski dziąsłowe szumiące, twarde $s z, r z, z, c z, d \dot{z}$ w opozycji do ciszących, miękkich $s^{\prime}, \dot{z}, \dot{c}, d \dot{z}^{\prime}, \dot{n}$, głoskę $r$ w opozycji do $l$ oraz $t \mathrm{w}$ opozycji do $l$, a także grupy spółgłoskowe". Jednak na podstawie obecnego rozporządzenia nauczyciel może odnosić wrażenie, że zbyt szczegółowe koncentrowanie się na zagadnieniach fonetycznych w nauce języka polskiego jako obcego jest kierunkiem błędnym, wystarczające jest bowiem założenie, że przyswajanie przez studenta wzorca prawidłowej wymowy polskiej jest procesem zachodzącym automatycznie, a jej doskonalenie postępuje naturalnie, w miarę coraz większego osłuchania się z językiem. Czy rzeczywiście można temu całkowicie zaufać?

Czynników pozadydaktycznych, które uznaje się za wpływające na proces przyswajania wymowy drugiego języka, jest wiele i mają one różną naturę: psychologiczną (jak motywacja, zainteresowanie, pamięć operacyjna, łatwość przyswajania informacji, rodzaj inteligencji, cechy osobowości, talent), neurologiczną (cechy budowy i funkcjonowaniu półkul mózgowych, zdolność kodowania fonetycznego), wynikające z indywidualnego doświadczenia studenta (znajomość innych języków obcych, wpływ wzorców języka ojczystego, przebyta edukacja muzyczna, ekspozycja na mowę w doświadczeniu pozaklasowym) (Stasiak 2017). W sumie tworzą one osobną konfigurację dla każdego ucznia i każdego stawiają w indywidualnej sytuacji. W praktyce manifestuje się to zresztą bardzo wyraźnie, bo rzadko się zdarza, żeby różnice w wymowie nie ujawniały się w grupie studentów już od samego początku nauki. Odwrócenie uwagi nauczyciela od tego zagadnienia w nadziei, że proces doskonalenia wymowy będzie z czasem równomiernie i u każdego samoistnie postępował, a obcowanie ze wzorcem wymowy będzie wystarczającym bodźcem do jej prawidłowego doskonalenia, wydaje się oparte na słabo umotywowanej nadziei.

W ostatnich latach coraz częściej słychać głosy upominające się o docenienie roli świadomego kształtowania postaci fonetycznej wypowiedzi w nauce języka 
polskiego jako obcego (Biernacka 2013, Gajewska 2017), wręcz wskazujące na fundamentalną rolę fonetyki w przyswajaniu innych podsystemów języka (Biernacka 2016, s. 43-45), czy ukazujące, jak bardzo poważnie typowe błędy wymowy cudzoziemców utrudniają zrozumienie ich wypowiedzi (Mirosławska 2013). Pojawiają się też wynikające z praktycznej obserwacji postulaty przeprowadzenia szerszych badań w zakresie przyswajania systemu fonologicznego u osób z różnymi językami natywnymi, które ułatwiłyby wzbogacanie podręczników o starannie zaplanowane ćwiczenia (Majewska-Tworek, Majewska 2014). Co prawda w używanych dziś podręcznikach do nauczania języka polskiego jako obcego ćwiczenia fonetyczne są obecne i w gruncie rzeczy prezentują bardzo wiele typów, zazwyczaj jednak nie są one przewidziane w cyklu regularnym ani opracowane kompleksowo pod względem zamysłu metodycznego, wykazują natomiast niedostatki technik nauczania. Zaniedbania te widoczne są zwłaszcza w podręcznikach podstawowych (Biernacka 2015a).

Przyłączam się do głosów podnoszących rolę kształtowania świadomości fonetycznej już od samego początku nauki języka polskiego, twierdząc, że jest to niezbędne nawet w wypadku kursów propedeutycznych, zaplanowanych w modelu ,survival”, których celem jest zaledwie wstępne oswojenie z językiem polskim i przygotowanie słuchacza do radzenia sobie w najbardziej podstawowych sytuacjach komunikacyjnych ${ }^{2}$ (Szmidt, Castellví 2011). Swoją opinię opieram na kilkuletnim doświadczeniu nauczania uczestników kursu przygotowawczego Premedical Course przygotowującego do podjęcia studiów w języku angielskim w Gdańskim Uniwersytecie Medycznym, w którego programie jest zaledwie 40-godzinny wstępny kurs języka polskiego. Uczestnikami tych kursów są przyszli studenci medycyny, zazwyczaj stanowiący mieszankę narodowościową z dużym udziałem osób pochodzących z krajów azjatyckich i afrykańskich, takich jak Arabia Saudyjska, Indie, Zjednoczone Emiraty Arabskie, Nigeria, Bahrajn, Syria, Egipt, Zambia, Singapur i studentów z Europy Zachodniej z azjatyckich rodzin imigranckich.

Jest oczywiste, że między językami istnieją różnice fonologiczne, fonetyczne oraz prozodyczne, które miewają walor fonologiczny. Nabywanie języka ojczystego wiąże się, by odwołać się tylko do przykładów zakresu zjawisk segmentalnych wymowy, z automatycznym przyzwyczajeniem do różnicowania słuchem cech opozycyjnych pod względem fonologicznym, czyli takich, które w danym języku wpływają na różnicowanie znaczeń, natomiast ignorowania niedystynktywnych cech głosek. I tak, dla rodzimego użytkownika języka polskiego o prawidłowo

${ }^{2}$ Warto zwrócić uwagę, że obowiązujące swego czasu, obecnie uchylone Rozporządzenie Ministra Edukacji Narodowej z dnia 1 lutego 2007 r. w sprawie ramowego programu kursów nauki języka polskiego dla uchodźców, określając liczbę godzin przeznaczonych na naukę języka polskiego w kursach ramowych przewidywało, że alfabetowi polskiemu i zagadnieniom fonetycznym należy poświęcić 35 na 200 godzin w grupie języków słowiańskich i 40 na 300 w grupie innych języków, co stanowi odpowiednio $17,5 \%$ i $13 \%$ całego wymiaru podstawowego kursu. 
rozwiniętym słuchu fonemowym oczywista będzie różnica realizacji fonetycznej w wyrazach park i bark, ale już nie przy - możliwym - dźwięcznym bądź bezdźwięcznym wymówieniu pierwszej głoski w wyrazie rtęć, ponieważ dźwięczność jako opozycja fonologiczna dotyczy tylko spółgłosek właściwych, ale już nie sonornych. Podobnie dziąsłowość, będąca cechą fonologiczną, która zawsze spowoduje automatyczne rozróżnienie na przykład pomiędzy [̌̌s] i [ś], [č] i [ć], czy zwartość różnicująca [̌̌ $\mathrm{i}$ [š]. Z kolei bez specjalnego treningu rodzimy użytkownik języka polskiego raczej nie rozpozna różnicy fonetycznej pomiędzy głoskami oznaczonymi grafemem $<\mathrm{w}>\mathrm{w}$ wyrazie wiadro i woda, grafemem $<\mathrm{n}>\mathrm{w}$ wyrazie ranczo i strona, grafemem $<\mathrm{a}>\mathrm{w}$ wyrazach matka i jajko, grafemem $<\mathrm{t}>$ w wyrazach potrzask, studnia i tik. Co w języku polskim jest cechą dystynktywną, w innym być nie musi, albo może mieć inny zakres i na odwrót - dość przytoczyć przykład zmiękczenia, które w języku polskim nie jest fonologicznie relewantne, a w języku rosyjskim tak, różnicując znaczeniowo np. wyrazy brat i brat'. W sumie zatem słuch fonematyczny kształcony jest naturalnie w każdym języku zgodnie z jego wymogami. Przekonują choćby o tym znane z doświadczenia każdemu, kto uczył się języka angielskiego, mającego dużo bogatszy zasób fonemów wokalicznych, kłopoty z rozróżnieniem słuchem i opozycyjną realizacją takich wyrazów jak cup i cap, end i ago, man i men czy anegdotycznej pary shit i sheet.

Samo różnicowanie słuchem opozycji nie jest wystarczające do prawidłowej realizacji danej głoski. W rozwoju mowy ich przyswajanie przebiega jako dłuższy, stopniowy proces oparty na autokorekcie słuchowej i kinestetycznej (narządów artykulacyjnych). W jego trakcie ich ruchy się sukcesywnie automatyzują, przyzwyczajając do coraz precyzyjniejszego zajmowania właściwych pozycji artykulacyjnych. Z czasem jednak plastyczność narządów artykulacyjnych zanika, podobnie jak osłabia się nieświadome nastawienie na dopracowywanie koordynacji słuchowo-kinestetycznej właściwej dla okresu rozwoju mowy, i tym trudniej, nawet przy dobrym różnicowaniu dźwięków, samodzielnie je prawidłowo realizować.

Kombinacja właściwości artykulacyjno-prozodycznych jest dla systemu każdego języka inna, toteż w zależności od przyzwyczajeń nim spowodowanych specyfika trudności w przyswajaniu polskiej wymowy dla studentów o różnych językach natywnych będzie inna i w różny sposób będzie wpływała na możliwość osiągnięcia wymowy przynajmniej satysfakcjonującej, czyli takiej, w której dla ucha rodzimego użytkownika poszczególne allofony będą identyfikowane jako realizacje właściwych fonemów. Będzie zatem zachodzić interferencja systemu języka natywnego. Stanowi to szczególnie problem w wypadku uczenia grupy różnojęzycznej, zwłaszcza takiej, w której są pochodzący z różnych krajów studenci nieeuropejscy, stanowią oni bowiem konfigurację osób o podłożu fonetycznym ukształtowanym przez języki rodzime w rozmaity sposób, a co za tym idzie - niepodobna przewidzieć wspólnych trudności, a jeśli się nie zna właściwości ich języków ojczystych - rodzaju ich interferencji fonetycznej. O tym, jak trudne jest przed nimi zadanie, przekonać może prosty praktyczny eksperyment, jakim 
jest przysłuchanie się wypowiedzi w ich rodzimym języku z zamiarem wydzielenia w nich choćby ,jednostek mowy” i próby imitacji którejkolwiek z nich po wysłuchaniu tylko jednego zdania. Obraz tego typu doświadczenia zderzenia z językami egzotycznymi odzwierciedlony jest w języku polskim, w którym istnieje frazeologizm siedzieć jak na tureckim kazaniu, a chińszczyzna ma znaczenie 'coś kompletnie niezrozumiałego' (To jest dla mnie chińszczyzna), które można też odnieść do nieumiejętności przebicia się przez barierę fonetyczną obcego języka.

Z mojego doświadczenia dydaktycznego wynika konieczność zapoznania studentów w takiej grupie z inwentarzem polskich fonemów i przećwiczenie ich podstawowych realizacji już na samym początku. Inaczej przed uczącym się stoi zadanie zupełnie samodzielnej, mozolnej analizy składu fonetycznego wyrazu wraz z próbami intuicyjnego operowania artykulatorami, których ruchy mogą być zautomatyzowane do zajmowania nieco innych pozycji. Mało realne jest niezwykle szybkie samodzielne powtórzenie drogi, którą się długo przechodziło w języku natywnym, opartej przecież na skomplikowanych operacjach przetwarzania bodźców słuchowych i ich przenoszenia na ruchy artykulatorów, do tego zazwyczaj w czasie, kiedy przekroczyło się już wiek krytyczny (w rozumieniu Erica Lenneberga 1967). Metodyczne wprowadzenie w system fonologiczny na początku nauki i tak nie jest w stanie na trwałe zniwelować tych trudności, o czym świadczą popełniane w późniejszym czasie częste błędy różnicowania słuchem form, teoretycznie już w toku nauki utrwalonych, lecz pojawiających się w nowych kontekstach, o tak odmiennych, jak wydawałoby się rodzimemu użytkownikowi polskiego, kształtach jak trzy i cztery, dziesięć i dziewięć, jedenaście i siedemnaście, trzynaście i trzydzieści. Interpretować to można chyba w ten sposób, że w trudniejszych uwarunkowaniach fonotaktycznych student jest w stanie wydobyć w analizie słuchowej tylko pojedyncze, najbardziej wyraziste dla niego lub najbliższe mu z punktu widzenia jego języka elementy segmentu, reszta zaś pozostaje słabo zidentyfikowana ${ }^{3}$. Pomocne w tym wypadku jest odwołanie się do wprowadzonej wiedzy, wskazanie przećwiczonych już swego czasu głosek nagłosowych: wyrazu i poszczególnych sylab, co pozwala na identyfikację miejsc trudnych, skoncentrowanie się na wydobyciu spółgłosek, których w wyrazie polskim jest zazwyczaj wiele. Jest ono zresztą pomocne już od pierwszych lekcji, nawet jeśli nie przewiduje się specjalnych trudności, ponieważ wyrazy, które występują w tym okresie nauki zawierają typowo polskie głoski, których pograniczna fonetyczna realizacja może doprowadzić do odczytania ich przez rodzimych użytkowników jako allofonów innych fonemów, takie jak Dzień dobry, dziękuję, cześć i liczebniki od 1 do 20, w których do tego występują zbitki spółgłoskowe. Odwoływanie się do wprowadzonych wzorców fonetycznych przydatne jest nieustannie, z wymienionych wyżej względów, przy wprowadzaniu nowych wyrazów, zwłaszcza mających trudniejszy kształt fonetyczny, po to by nawet te „wyuczone” były zrozumiałe,

${ }^{3} \mathrm{Na}$ konieczność diagnozowania słuchowego zróżnicowania dźwięków mowy z uwzględnieniem złożonych struktur fonologicznych wyrazu zwraca uwagę Majewska-Tworek (2006, s. 106). 
by stanowiły dalszy wzorzec wymowy i nie utrwalały błędnych nawyków wymawianiowych. Trudno je potem poddawać kolejnym modyfikacjom, a jak to ujmuje Elżbieta Gajewska: „uczeń z utrwaloną niepoprawną wymową to uczeń, któremu wyrządzono dydaktyczną krzywdę" (Gajewska 2017, s. 50).

Wprowadzania głosek warto dokonać w modelu kontrastywnym w szczególności w odniesieniu do tych, które mogą w przyszłości nastręczyć problemów. Uwzględnić tu należy dwa czynniki: opozycje fonologiczne w języku polskim, które-zniesione w nieprawidłowej realizacji - mogą spowodować zniekształcanie wyrazu w taki sposób, że stanie się on niezrozumiały, i występowanie ćwiczonych głosek w pozycjach morfemów fleksyjnych, ich zniekształcanie bowiem uczynić może w przyszłości omawianie niektórych zagadnień gramatycznych jałowym. Z całą pewnością do pierwszej grupy zaliczyć można typową dla polszczyzny opozycję szeregów szumiącego, ciszącego i syczącego, których różnicowanie sprawia kłopoty chyba wszystkim ${ }^{4}$. Zazwyczaj języki mają takie szeregi (choć nie zawsze aż trzy), lecz ich ekwiwalenty w innych językach są zwykle wymawiane w sposób tylko podobny. Jolanta Tambor zwraca uwagę na to, że najtrudniejsze do opanowania są właśnie głoski zbliżone do głosek występujących w językach rodzimych. Przy trudnej do uchwycenia słuchem różnicy i utrwalonych własnych nawykach artykulacyjnych uczący się zastępuje nimi głoski w języku nabywanym (Tambor 2010, s. 33). Kłopoty z realizacją tych szeregów są jedną z najczęściej obserwowanych u studentów różnych narodowości (Kijewska 2001; Majewska-Tworek 2006; Kaleta 2010; Tambor 2010; Szmidt, Castellví 2011; Mirosławska 2013; Młynarczyk 2013; Biernacka 2015b, 2016, s. 111-114), przy czym - można oszacować ze względu na ich liczbę w systemie konsonantycznym i frekwencję występowania, jak również ocenić na podstawie obserwacji nauczycieli (Biernacka 2015b) - są one jedną z najczęstszych przyczyn zakłóceń komunikacyjnych .

$\mathrm{Z}$ samogłosek powszechnie trudne jest zróżnicowanie [y] oraz [e], podobnie często odpowiedzialne za powstawanie zakłóceń komunikacyjnych (Biernacka 2015b, 2016, s. 106-108). Przy trudnościach z dokładną artykulacją [y] w wymowie spontanicznej bywa ono też zastępowane przez [i] (Madelska 2010, s. 47) ${ }^{5}$. Niedokładna wymowa tych głosek może przynieść nieporozumienia komunikacyjne np. w przypadku wyrazów wyjście: wejście, przeszłość: przyszłość, była: biła, myła: miła, ale też w kwestiach fleksyjnych, są one bowiem końcówkami

${ }^{4}$ Większość tych fonemów nie należy do rzadkich w języku polskim. Przynajmniej jeden reprezentant każdego szeregu znajduje się w pierwszej połowie listy frekwencyjnej fonemów niesamogłoskowych. W uporządkowaniu rangowym wszystkich fonemów polskich (w sumie 39: 6 samogłoskowych, 33 niesamogłoskowe) pozycję tę zajmują: [s] -12 , /šs $/-19, / \mathrm{z} /-21, / \mathrm{c} /-23$,

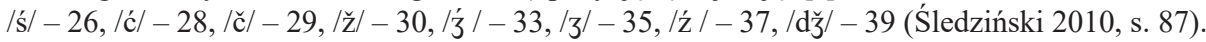

${ }^{5}$ Różnice artykulacyjne i akustyczne pomiędzy głoską [y] oraz [i] oraz [e], a zwłaszcza [è], będącym wariantem pozycyjnym fonemu /e/ nie są tak duże jak w przypadku innych samogłosek. Ponadto, jak pisze B. Wierzchowska w odniesieniu do wymowy Polaków: „Samogłoska y jest bardziej polimorficzna niż samogłoska $i$. Przedłużana, łatwo przechodzi w e lub $i$." (Wierzchowska 1971, s. 125). 
form fleksyjnych rzeczownika i przymiotnika wskazującymi na różne wartości kategorii fleksyjnych. Przy niewyćwiczonym ich zróżnicowaniu wszelkie zadania sprawdzające poprawność gramatyczną w parach w rodzaju $d$ wa grosze: pięć groszy, czerwony pomidor: czerwone pomidory, gruby chłopiec: grubi chłopcy można przedstawiać i weryfikować tylko w postaci ortograficznej.

Przy okazji samogłosek warto zwrócić uwagę na kwestie prozodyczne. W wielu językach samogłoski ulegają redukcji, co zmniejsza ich wyrazistość, a także zmienia jakość artykulacyjną. Realizacje tego typu wzmacniają zakłócenia postaci fonetycznej wyrazu podwójnie, ponieważ jednocześnie powodują nagromadzenie zaburzonych fonetycznie spółgłosek (jeśli są one tak wymawiane). Tymczasem, jeśli ująć fonem w znaczeniu kognitywnym, jak proponuje Jolanta Szpyra-Kozłowska, widząc w nim nie tyle jednostkę różnicującą odmienne znaczeniowo formy wyrazowe, ale jako segment tkwiący w umyśle mówiącego i zamierzony przez niego w danym akcie mowy (Szpyra-Kozłowska 2002, s. 91) - co w konsekwencji dotyczy także oczekiwań słuchacza w odbiorze - można przypuszczać, że łatwiej będzie mu na podstawie niezaburzonego przynajmniej szkieletu samogłoskowego odtworzyć zamierzenia mówiącego, zwłaszcza że wiedza językowa podpowiada mu niczym w grze możliwe warianty wypełnienia całej struktury tak, aby powstał wyraz, a kontekst językowy pozwala te możliwości przeselekcjonować (co oczywiście uruchamia się zawsze, nie tylko w wypadku samogłosek).

Wprowadzanie fonemów polskich ma sens z jednoczesnym odwołaniem się do alfabetu. Student obcojęzyczny, poznając język polski, znajduje się w innej sytuacji niż jego rodzimy użytkownik. Naturalne dla przyswajania języka ojczystego jest poznawanie go najpierw w postaci mówionej, później dopiero poznaje się konwencję ortograficzną zapisu. Osoba ucząca się języka obcego w klasie poznaje oba kody: fonologiczny i graficzny równolegle ${ }^{6}$. Ma to i wady, i zalety. Z jednej strony postać ortograficzna jest podpowiedzią dotyczącą wymowy, z drugiej zaś strony, jeśli się nie zna konwencji przełożenia elementów fonologicznych na graficzne, stać się może podpowiedzią mylącą. Metodyczne koncentrowanie się jeszcze na ortografii może się wydawać za dużym obciążeniem dla studenta, ale mimo że w języku polskim istnieją rozbieżności między pismem a mową, najważniejsze te zależności są w miarę regularne i możliwe do przedstawienia. Zaprezentowanie podstawowych ortograficznych reprezentacji fonemów w kontekstach, w których realizowane są one przez warianty podstawowe i w pozycjach neutralizowanych wydaje się wystarczające $z$ dydaktycznego punktu widzenia. Ograniczenie to jest

${ }^{6}$ G. Balkowska przedstawiła swoje obserwacje dotyczące grupy wielojęzycznej, z których wynikało, że u studentów, którym jednocześnie nie wprowadzano alfabetu, szybciej rozwijał się słuch fonematyczny i skuteczniej opanowywali oni artykulacyjne wzorce kinestetyczne, ale po pierwsze w opisywanej grupie przewagę mieli studenci afrykańscy, którzy zazwyczaj mają naturalny kontakt z wieloma językami używanymi w kraju rodzimym i poznają je tylko w wersji mówionej, po drugie zaś dla grupy tej przewidziany był długi kurs, w którym można było poświęcić pierwsze 20 godzin na wyrabianie słuchu fonematycznego $\mathrm{w}$ trakcie poznawania języka przez słuchanie i powtarzanie (Balkowska 2004). 
również uzasadnione z punktu widzenia wiedzy fonetycznej. Takie zjawiska jak zasada jednorodności grupy spółgłosek właściwych pod względem dźwięczności realizowana w tzw. upodobnieniach martwych (jak np. w wyrazach krzesto i owca, wbrew sugestii pisma, że grupa spółgłoskowa zawiera i dźwięczną, i bezdźwięczną głoskę) czy zasada bezdźwięcznej realizacji spółgłoski właściwej w wygłosie absolutnym nie są co prawda w językach uniwersalne, ale wynikają z ekonomii wysiłku artykulacyjnego i można sądzić, że z tego względu zostaną przyswojone samoistnie (to ewentualne utrzymanie tej niejednorodności wymagałoby właśnie pracy nauczyciela) ${ }^{7}$. Podobnie zasada śródwyrazowej realizacji fonetycznej grafemów $<$ ą $>$ i $<$ ę $>$ w pozycji przed zwartymi i zwarto-szczelinowymi: głoska półotwarta nosowa pojawiająca się jako drugi segment w ich wymowie ma takie miejsce artykulacji jak głoska następna, zatem jej realizacja przychodzi naturalnie.

Wprowadzanie fonemów łącznie $\mathrm{z}$ ich reprezentacją ortograficzną daje studentowi samodzielność w obcowaniu z tekstem zapisanym i zwrotnego wykorzystania postaci ortograficznej wyrazu dla odtworzenia wzorca artykulacyjnego. Minimalizuje się w ten sposób jednocześnie prawdopodobieństwo wystąpienia w przyszłości błędów wymowy o charakterze interferencji ortograficznej, polegającej na odczytywaniu wyrazów (nie tylko nowych, ale też takich, których wymowy student nie pamięta) zgodnie z konwencją ortograficznej reprezentacji fonemów własnego języka (lub innego, np. angielskiego) np. takich jak cukier w realizacji [kuk'er], co $\mathrm{w}$ realizacji [ko] lub groch $\mathrm{w}$ realizacji [groš], połowa w realizacji [polouna], Włochy $\mathrm{w}$ realizacji [ullošy], gotówka $\mathrm{w}$ realizacji [gotoukk], jest $\mathrm{w}$ realizacji [క̌est], które już zdecydowanie powodują zakłócenia komunikacji. Trzeba bowiem pamiętać, że polskie leksemy w nauce języka polskiego jako obcego, zarówno w klasie lekcyjnej, jak i w środowisku naturalnym, przyswajane są drogą podwójną: przez obcowanie ze wzorcem słuchowym, ale też graficznym.

Możliwość samodzielnego odczytywania polskiego tekstu technicznie już od początku nauki wyposaża jednocześnie studentów w ważną umiejętność potrzebną do samodzielnego poruszania się w środowisku rzeczywistości polskojęzycznej i pomaga oswajać je kulturowo. Mam tu na myśli szansę zrozumiałego operowania nazwami własnymi, takimi jak nazwy ulic, dzielnic ${ }^{8}$ czy przystanków w otoczeniu, w którym porusza się student, operowania nazwami miejscowości polskich, do których może na przykład zechcieć kupić bilet kolejowy. Rozpoznanie ich ze słuchu, związanie z postacią ortograficzną i akceptowalna realizacja fonetyczna zapewniają cudzoziemcowi podstawowy stopień niezależności w otoczeniu obcojęzycznym. Można przewidywać, że student po krótkim kursie, czyli o bardzo słabej jeszcze kompetencji językowej w zakresie polskiego, będzie się $\mathrm{w}$ istotnych sytuacjach komunikacyjnych poza klasą lekcyjną próbował posłu-

${ }^{7}$ Utrata dźwięczności w wygłosie absolutnym dotyczy nawet fakultatywnie samogłosek (w wypowiedziach o intonacji opadającej, po spółgłosce bezdźwięcznej) (Sawicka 1995, s. 125).

${ }^{8}$ Przykładowo w Gdańsku centralne komunikacyjnie dzielnice nazywają się: Wrzeszcz, Strzyża, Przymorze, Brzeźno. 
giwać raczej językiem angielskim. Wobec nazw własnych, jeśli nie będzie ich umiał wymówić czy odczytać prawidłowo, i tak pozostanie w tej sytuacji bezradny, a skutkiem tego komunikacyjnie nieskuteczny, ponieważ onimy z natury swojej nie są thumaczone, a nazwy ściśle lokalne nie mają innojęzycznych odpowiedników.

Rozważania na temat tego, po co i jak (nie) uczyć cudzoziemców fonetyki na lekcjach polskiego ograniczyłam tu tylko do jednej sytuacji - początkowego etapu nauki. Zasadność wprowadzenia elementów wiedzy fonetycznej do nauki na stosunkowo wczesnym etapie daje się przede wszystkim wykazać z odwołaniem do niej samej. Nie da się precyzyjnie opisać takiego zakłócenia postaci fonetycznej wyrazu, która obiektywnie spowodowałaby jego niezrozumiałość w odbiorze, choć być może badań tego zagadnienia można by się podjąć. Zależne jest ono od wielu czynników. Od strony nadawcy jest to (w ograniczeniu do omawianych tu zjawisk segmentalnych) realizacja fonetyczna fonemów, przy czym trudno opisać takie realizacje i wyznaczyć pomiędzy nimi granice, których przekroczenie powoduje, że w odbiorze dana głoska jest odczytywana jako realizacja innego fonemu. Od strony przekazu jest to postać wyrazu, jego skład fonologiczny: ilość, jakość i struktura, a także kontekst językowy i sytuacyjny wypowiedzi. Od strony nadawcy rozstrzyga o tym umiejętność dekodowania hipotetycznych segmentów fonologicznych wyrazu. Istnienie zakłóceń fonologicznych i ich najbardziej charakterystyczne postaci można jednak przewidywać nie tylko na podstawie doświadczenia, lecz na podstawie wiedzy o samym zjawisku, jakim jest dźwiękowa postać mowy. Metodyka podsuwa rozwiązania modelowe, uniwersalne, wynikające z negocjowania wiedzy i praktyki, z konieczności są to jednak rozwiązania o pewnym stopniu ogólności. Specyfiką zawodu nauczyciela jest to, że wymaga on nieustannej elastyczności, szukania rozwiązań w sytuacjach nowych, nieprzewidywanych, dostosowania się do zmieniających się warunków, bo przecież jego wysiłek skierowany jest na drugiego człowieka. Działania nauczyciela z natury swojej nie podlegają więc wzorcom algorytmicznym. Wiedza z zakresu fonetyki i fonologii pozwala jednak niektóre zjawiska przewidywać, świadomość mechanizmu powstawania niepożądanych realizacji - trafnie planować swoje działania i reagować właściwie w konkretnych sytuacjach. Niestety wiele podręczników i zamieszczanych w Internecie materiałów ułatwiających naukę języka polskiego ujawnia, że świadomość i wiedza nauczycieli w tym względzie niejednokrotnie jest niewystarczająca: zagadnienia fonetyczne są często ujmowane bez kontekstu, są słabo powiązane z innymi poziomami języka i celami nauczania, występują też rażące błędy. Te ostatnie można zwłaszcza obserwować w zamieszczanych na kanale You Tube filmikach zapoznających z polskim alfabetem i prezentujących lekcje polskiej wymowy, których autorzy przedstawiają się często jako zawodowi nauczyciele języka polskiego jako obcego?

${ }^{9} \mathrm{~W}$ materiałach tych powszechnie występują takie błędy jak mylenie pojęcia głoski i litery czy prezentowanie wymowy głoski na przykładach wyrazów, w których ona nie występuje, por. https:// 


\section{BIBLIOGRAFIA}

Balkowska G., 2004, Nauczanie wymowy polskiej w grupie wielojęzycznej, w: A. Dąbrowska (red.), Wrocławska dyskusja o języku polskim jako obcym. Materiaty z Międzynarodowej Konferencji Stowarzyszenia ,, Bristol”, Wrocław, s. 247-254.

Biernacka M., 2013, Pojęcie kompetencji fonologicznej vel fonetycznej-rozważania terminologiczne, „Acta Universitatis Lodziensis. Kształcenie Polonistyczne Cudzoziemców”, t. 20, Glottodydaktyka-media-komunikacja. Kształtowanie kompetencji komunikacyjnej, I. Dembowska-Wosik i E. Pałuszyńska (red.), s. 75-82.

Biernacka M, 2015a, Nauczanie fonetyki języka polskiego jako obcego w świetle technik nauczania wybieranych przez autorów współczesnych podręczników, w: M. Gaze, P. Góralczyk-Mowczan (red.), Bogactwo językowe i kulturowe Europy w oczach Polaków i cudzoziemców 3, Łódź, s. 20-37.

Biernacka M., 2015b, Trudności w nauczaniu wymowy polskiej cudzoziemców w świetle wyników badań ankietowych, „Acta Universitatis Lodziensis. Kształcenie Polonistyczne Cudzoziemców”, t. 22, G. Zarzycka (red.), s. 251-265.

Biernacka M., 2016, Znajdź z polskim wspólny język. Fonetyka w nauczaniu języka polskiego jako obcego. Poradnik metodyczny, Łódź.

Coste D., North B., Sheils J., Trim J., 2003, Europejski system opisu ksztatcenia językowego: uczenie się, nauczanie, ocenianie, Warszawa. (ESOKJ), https://www.ore.edu.pl/wp-content/uploads/ attachments/ESOKJ_Europejski-System-Opisu.pdf [25.04.2018].

Gajewska E., 2017, Gdy podręcznik zawodzi. Rady dla nauczycieli dbajacych o wymowę swoich uczniów, „Języki Obce w Szkole”, nr 2, s. 48-57.

Izdebska-Długosz D., 2016, Uczyć czy nie uczyć? - Przemiany miejsca i roli gramatyki w świetle metod nauczania języków obcych, „Acta Humana”, t. 7, s. 93-103.

Kaleta R., 2010, Błędy fonetyczne Białorusinów uczacych się języka polskiego, „Lingwistyka Stosowana", t. 2, s. 121-132.

Kijewska A., 2001, Butgarskie interferencje fonetyczne w języku polskim a błąd glottodydaktyczny (na materiale prac pisemnych studentów bułgarskich), w: R. Cudak, J. Tambor (red.), Inne optyki. Nowe programy, nowe metody, nowe technologie w nauczaniu kultury polskiej i języka polskiego jako obcego, Katowice, s. 263-274.

Lenneberg E. H., 1967, Biological foundations of language, New York.

Madelska L., 2010, Postuchaj, jak mówię. Poradnik dla rodziców i nauczycieli. Materiały do ćwiczenia stuchu i wymowy dla dzieci oraz dla obcokrajowców, uczących się języka polskiego jako obcego, Wiedeń.

Majewska-Tworek A., 2006, Fonetyczne interferencje i asymilacje $w$ analizie wymowy polskiej u niemieckojęzycznych studentów, „Acta Universitatis Wratislaviensis”, nr 2907, „Studia Linguistica", t. XXV, Wrocław, s. 103-110.

Majewska-Tworek A., Majewska A., 2014, Nauczanie wymowy polskiej jako obcej-teoria i praktyka, w: A. Dąbrowska, U. Dobesz (red.), 40 lat wroctawskiej glottodydaktyki polonistycznej. Teoria i praktyka, Wrocław, s. 277-290.

www.youtube.com/watch?v=CQzHVb0n6Y8; https://www.youtube.com/watch?v=kTsK-J4pLEo; https://www.youtube.com/watch?v=cwhRqMW9BYo; https:/www.youtube.com/watch? $\mathrm{v}=\mathrm{cH}-$ GR1qUAi5A; https:/www.youtube.com/watch?v=y85UXdDBQMg; https://www.youtube.com/ watch? $\mathrm{v}=\mathrm{GMNrx} 2 \mathrm{c} 7 \mathrm{~b} 50$; https://www.youtube.com/watch?v=UcLq7qS9xBw; https://www.youtube.com/watch?v=MfSz9ov4aZM; https://www.youtube.com/watch?v=eBxVF4GjSFY; https:// www.youtube.com/watch?v=20pDtDSqT3Y; https:/www.youtube.com/watch?v=k6QTgtcApB4; https://www.youtube.com/watch?v=TSreBClqSUQ; https:/www.youtube.com/watch?v=aJI6JDAxUd4; https://www.youtube.com/watch?v=-bmOlCI-BCY; https://www.youtube.com/watch? $v=\mathrm{m}$ cQERrqxClM; https://www.youtube.com/watch?v=2lwrevnAn1g\&t=17s 
Mirosławska W., 2013, Trudne miejsca w nauczaniu wymowy polskiej w środowisku bułgarskojęzycznym, „Postscriptum Polonistyczne”, nr 2, s. 303-309.

Młynarczyk M., 2013, Artykulacja polskich głosek u chińskich studentów uczacych się języka polskiego, „Acta Universitatis Wratislaviensis”, nr 3551, „Studia Linguistica”, t. XXXII, Wrocław, s. 133-145.

Rozporządzenie Ministra Edukacji Narodowej i Sportu z dnia 15 października 2003 r. w sprawie egzaminów z języka polskiego jako obcego, Dz.U. 2003, nr 191, poz. 1871.

Rozporzadzenie Ministra Edukacji Narodowej z dnia 1 lutego 2007 r. w sprawie ramowego programu kursów nauki języka polskiego dla uchodźców, Dz.U. 2007, nr 35, poz. 221.

Rozporzadzenie Ministra Nauki i Szkolnictwa Wyższego z dnia 26 lutego 2016 r. w sprawie egzaminów z języka polskiego jako obcego, Dz.U. 2016, poz. 405.

Sawicka I., 1995, Fonologia, [w:] L. Dukiewicz, I. Sawicka (red.), Fonetyka i fonologia, Kraków, s. $107-195$.

Stasiak S., 2017, O czynnikach wpływajacych na przyswajanie wymowy języka obcego (zwłaszcza w kontekście szkolnym), „Języki Obce w Szkole”, nr 2, s. 20-24.

Szmidt D., Castellví J., 2011, Cechy charakterystyczne fonetyki polskiej w nauczaniu Katalończyków, w: R. Nycz, W. Miodunka, T. Kunz (red.), Polonistyka bez tajemnic, Kraków, s. 197-208.

Szpyra-Kozłowska J., 2002, Wprowadzenie do wspótczesnej fonologii, Lublin.

Śledziński D., 2010, Fonemy, difony, trifony i sylaby - charakterystyka jednostek na podstawie korpusu, „Kwartalnik Językoznawczy”, nr 3-4, s. 84-113.

Tambor J., 2010, Nauczanie wymowy polskiej. Trudności różnych grup cudzoziemców, w: A. Achtelik, M. Kita, J. Tambor (red.), Sztuka i rzemiosło. Nauczyć Polski i polskiego, t. 2, Katowice, s. $30-51$.

Wierzchowska B., 1971, Wymowa polska, Warszawa.

\title{
Ewa Badyda
}

\section{WHY AND HOW (NOT) TO TEACH POLISH PHONETICS TO FOREIGNERS?}

Keywords: teaching Polish as a foreign language, phonetics, phoneme, phone

\begin{abstract}
Communicative language teaching does not focus its attention on phonetics, but it should be noted that student's communicative efficiency also depends on his ability to reproduce the phonetic shapes of words correctly. The student's difficulties with the correct pronunciation in a foreign language are the result of shaping his phonological hearing and automation of movements of the articulators by his native language. That is why just exposure to the sound of the L2 may not be enough. The author argues that identifying Polish phones and their correct production should be focused on from the beginning. This allows the teacher to refer to correct patterns of phones in any prospective case of wrong pronunciation and also helps prevent the formation of erroneous student's habits of speech. In the work on phonetics, particular attention should be paid to the most characteristic phonological oppositions in Polish, also taking into account those important from the point of view of inflection. It would be advisable to introduce phonemes simultaneously with the alphabet, as in classroom learning conditions a student acquires phonic and graphic forms of words at the same time. Equipped with the knowledge about the relationship between pronunciation and spelling, he will be able to correct his own pronunciation referring to the spelling of the words and also - to write them as they are heard. It also prevents a student from reading newly learned words according to the spelling rules of another language. In the future, it will allow the student to pronounce those proper names, which are learned in graphic form, correctly.
\end{abstract}

